\title{
PENGARUH PELATIHAN BERBASIS MINDFULNESS TERHADAP TINGKAT STRES PADA GURU PAUD
}

\author{
Ega Asnatasia Maharani \\ Universitas Ahmad Dahlan \\ Email: ega@pgpaud.uad.ac.id
}

\begin{abstract}
Abstrak
Guru merupakan profesi yang rentan mengalami stres. Mindfulness sebagai salah satu strategi emotional coping merupakan alternatif intervensi yang dapat membantu guru mengatasi kondisi stres yang dialaminya. Pelatihan "Smiling Mind" (SM) yang digunakan sebagai intervensi stres ini menggunakan konsep Mindfulness Based Stress Reduction dan Mindfulness Based Cognitive Therapy. Melalui pelatihan SM ini diharapkan guru dapat meningkatkan mindfulness sebagai sumber daya koping sehingga pada akhirnya mampu menurunkan stres kerja. Partisipan dalam pelatihan adalah 5 guru PAUD berusia 20-35th yang mengajar di TK Khalifah Yogyakarta. Metode penelitian yang digunakan kuasi eksperimen the one group pretest-posttest design dengan desain small group. Pelatihan SM dilaksanakan selama jangka waktu 2 minggu, dengan 7 sesi dalam 3 pertemuan berdurasi 150-180 menit per pertemuan. Hasil penelitian menunjukkan ada perbedaan tingkat stres guru sebelum dan sesudah pelatihan, sehingga pelatihan Smiling Mind efektif menjadi intervensi psikologis guru. Penurunan skor terbesar ada pada aspek fisik, dilanjutkan aspek emosi, perilaku dan kognitif. Protokol pelatihan berbasis mindfulness dapat dikembangkan sebagai alternatif intervensi penanganan masalah stres guru.
\end{abstract}

Kata kunci: guru, stres, mindfulness

\section{MINDFULNESS BASED INTERVENTION FOR EARLY CHILDHOOD EDUCATION TEACHERS}

\begin{abstract}
Teacher is a profession at high risk of stress. Mindfulness as one of the emotional coping strategy is an alternative interventions that can help teachers cope with stress condition. Smiling Mind training used in this study was a form of intervention to manage stress which developed based on the concept of Mindfulness Based Stress Reduction (MBSR) and Mindfulness Based Cognitive Therapy (MBCT). Participants involved in the study were 5 early childhood education teacher age 20-35in TK Khalifah Yogyakarta. The study was an quantitative research which used quasi experiment model and the one group pretest-posttest design. SM training was conducted for two weeks, involving 7 sessions within 3 days of meeting with duration of 150-180 minutes per meeting. Result of quantitative analysis showed that SM training could reduce stress level of early childhood education teachers which was shown by $z$ score of $-2,023$ and $p=0,043(p<0,05)$. This results indicated that mindfulness based training is suitable to be developed to overcome teacher's stress problem.
\end{abstract}

Keywords: teacher, stress, mindfulness

\section{PENDAHULUAN}

Guru memiliki tanggung jawab utama untuk mendidik dan mengembangkan potensi peserta didik. Akan tetapi faktanya di lapangan guru juga memiliki berbagai tanggung jawab lain yang berkaitan dengan tugas mengajar seperti: mempelajari ilmu dan ketrampilan baru, 
menguasai teknologi yang sedang berkembang, serta berurusan dengan orangtua murid dan komunitas sekolah. Di samping itu guru juga dituntut untuk memenuhi berbagai standard dan target baik dari wali murid, institusi tempatnya bekerja hingga pemerintah.

Berbagai tuntutan ini menunjukkan bahwa guru adalah salah satu profesi yang memiliki tuntutan tinggi sehingga rentan mengalami stress, burnout (Flook et al, 2013:182), regulasi emosi yang rendah (Roeser et al, 2012:167); dan terganggunya kebahagiaan pribadi (Schoeberlein, 2009:54). Sedangkan sebuah penelitian yang dilakukan oleh Bauer et al (2006:199) juga menemukan bahwa di negara-negara berkembang, guru merupakan profesi yang memiliki tingkat kelelahan emosi (burnout) yang tinggi.

Stres merupakan suatu kondisi dimana individu menilai sumberdaya atau kemampuan yang dimiliki tidak sebanding dengan tekanan dari luar. Dalam dunia kerja tekanan ini dapat berasal dari kondisi eksternal seperti lingkungan fisik, beban kerja, maupun relasi dengan atasan maupun rekan kerja. Sementara prediktor dari kondisi internal yang dapat memicu stres antara lain karakteristik pribadi yang memiliki harga diri rendah, kurang percaya diri, dan rendahnya efikasi diri.

Berdasarkan data awal yang didapat melalui wawancara beberapa guru TK di Yogyakarta, peneliti mengidentifi-kasi beberapa permasalahan yang menimbulkan tekanan bagi guru antara lain keharusan mengikuti inovasi dan perubahan yang serba cepat, rendahnya kesejahteraan guru, administrasi dan iklim sekolah, hubungan dengan teman sejawat, wali murid, dan komunitas, serta problem manajemen kelas. Berbagai tekanan yang dialami ini kemudian diakui mempengaruhi kualitas mengajar guru di sekolah. Flook et al (2013:183) menyatakan, guru yang bertahan dengan pekerjaannya namun mengalami stres secara terus menerus dapat mempengaruhi responsivitas guru terhadap siswa dan mempengaruhi kemampuan guru dalam manajemen kelas.

Dalam praktiknya, profesi guru PAUD dituntut terlibat secara fisik dengan kegiatan peserta didik sehingga membutuhkan kesiapan yang matang. Sangat jarang dalam praktik mengajarnya guru PAUD memiliki kesempatan untuk duduk dan beristirahat karena kondisi kelas cenderung terus bergerak dinamis. Guru PAUD juga dituntut untuk memiliki kesiapan mental karena berhadapan dengan anak usia dini yang membutuhkan penanganan secara individual. Rutinitas semacam ini tanpa disadari dapat membuat guru berada pada tahap mindlessness, yang menyebabkan timbulnya perasaan kehilangan kontrol terhadap kondisi kelas dan perasaan frustasi menghadapi peserta didiknya. Mindlessness sebagaimana didefinisikan Langer (Snyder dan Lopez, 2007:34) merupakan saat di mana pikiran individu terperangkap dalam pola pemikiran yang dangkal sehingga tidak mampu memahami konteks suatu peristiwa secara utuh. Hal ini menyebabkan guru kurang mampu memaknai peristiwa yang dialaminya dan tidak mampu merespon peristiwa tersebut dengan tepat. Apabila kondisi ini terjadi secara terus menerus, perasaan frustasi tersebut dapat mengarah pada timbulnya stres.

Menanggapi hal ini, para ahli filosofi, spiritual, hingga psikologi telah sepakat menggarisbawahi pentingnya faktor kesadaran (consciousness) terhadap kesejahteraan diri dan tercapainya fungsi manusia yang optimal (Brown dan Ryan, 2003:822). Salah satu atribut kesadaran yang telah banyak mendapat perhatian untuk didiskusikan dan diteliti adalah mindfulness, dimana konsep dasar mindfulness sendiri adalah tahapan dimana individu mampu memberi perhatian dan menyadari apa yang sedang terjadi saat ini tanpa bersikap reaktif terhadap keadaan tersebut. Kabat-Zinn (1990:87) mendefinisikan mindfulness sebagai kesadaran yang muncul akibat memberi perhatian terhadap sebuah 
pengalaman saat ini secara disengaja dan tanpa penilaian agar mampu merespon dengan penerimaan, dan bukannya bereaksi, terhadap pengalaman yang dialami sehari-hari. Melalui mindfulness, kondisi stres yang seringkali dianggap menekan akan mampu dilihat dan dimaknai secara berbeda. Individu tidak lagi merasa terancam dengan sumber stres melainkan memiliki kejernihan berpikir untuk merespon stres tersebut.

Terbatasnya intervensi terhadap kondisi psikologis guru dan pengaruhnya pada kualitas pendidikan khususnya di lingkungan PAUD Yogyakarta mendorong peneliti untuk memfokuskan penelitian ini pada variabel yang berkaitan dengan fungsi psikologis yang positif dari individu yaitu mindfulness.

Indonesia sebagai salah satu negara berkembang harus terus berupaya mencari solusi bagi permasalahan stres guru dalam mengajar, karena jika tidak maka akan problem ini akan berpengaruh pada kualitas pendidikan secara umum. Eksplorasi mendalam pada konstruk positif ini diharapkan dapat digunakan sebagai sumberdaya untuk mengatasi permasalahan stres pada guru dan dapat menjadi bahan rujukan bagi pengembangan program-program preventif yang dapat meningkatkan kinerja dan kesehatan psikologis guru. Berdasarkan uraian tersebut, maka peneliti mengambil kesimpulan sementara bahwa pelatihan berbasis mindfulness perlu diukur untuk mengetahui keefektifannya terhadap penurunan stres guru.

\section{Stres Guru}

Stres adalah kondisi ketika sebuah peristiwa yang dialami individu menyebabkan ketegangan fisik, mental, ataupun emosional (McCormick \& Barnett, 2011:278). Lazarus (Taylor, 2006) menegaskan bahwa stres terjadi ketika kemampuan atau sumber daya yang dimiliki seseorang dinilai tidak mencukupi untuk mengatasi tuntutan situasi. Sementara itu Baum (dalam Taylor, 2006:83) mengatakan bahwa stres adalah pengalaman emosi negatif, dan tekanan untuk beradaptasi dengan kondisi serta norma sosial yang diikuti oleh perubahanperubahan fisiologis, kognitif, dan perilaku secara langsung terhadap munculnya kejadian yang dianggap menekan, tidak terkontrol, dan diluar kemampuan individu untuk mengatasinya

Berdasarkan definisi di atas peneliti menyimpulkan bahwa stres adalah kondisi ketika tekanan atau stresor dipersepsi negatif karena individu tidak memiliki sumber daya yang memadai untuk mengatasinya sehingga menimbulkan masalah pada aspek fisik, kognitif, emosi, dan perilaku. Selanjutnya peneliti menurunkan definisi stres tersebut ke dalam beberapa aspek, yaitu:

1. Aspek fisik

Aspek ini ditandai adanya gangguan fisik, kelelahan, kualitas makan dan tidur terganggu. Timbulnya gangguan ini bukan berasal dari penyakit fisik melainkan sinyal adanya beban yang dirasakan tubuh 2. Aspek emosi

Aspek ini ditandai adanya labilitas perasaan, kecemasan, dan penurunan minat terhadap aktivitas.

3. Aspek kognitif

Aspek ini ditandai adanya persepsi negatif baik terhadap diri sendiri maupun lingkungan

4. Aspek perilaku

Aspek ini ditandai dengan timbulnya perilaku menghindar atau melawan sebagai bentuk luapan stres.

Flook et al (2013:45) menyebutkan ada beberapa sumber stres guru yang secara umum sering ditemukan yaitu jam kerja, beban kerja yang berlebihan perilaku siswa yang sulit dikendalikan, serta faktor organizational. Sementara menurut McCallum \& Price (2010:19) stres guru disebabkan oleh meningkatnya standar kerja yang harus dicapai, beban kerja yang berat, serta peningkatan permintaan siswa. Di Indonesia penelitian yang spesifik mengenai penyebab stres guru PAUD belum ditemukan, namun hasil penelitian 
Khilmiyah (2012:145) yang meneliti tentang stres guru perempuan di wilayah Bantul Yogyakarta menyebutkan beberapa sumber stres guru yang ditemukan antara lain: tugas rumah dan kantor yang bersamaan, disiplin ketat, tuntutan karier, suasana kantor tidak nyaman, atasan yang otoriter, serta hal-hal yang berkaitan dengan kenaikan pangkat atau jabatan. Berbagai faktor penyebab stres yang ditemukan ini mengindikasikan bahwa stres merupakan masalah psikologis yang membutuhkan penanganan segera karena dapat muncul dari berbagai sumber sekaligus dan dapat berimplikasi pada kualitas mengajar yang dihasilkan. Jennings \& Greenberg (2009:500) menyebutkan, guru yang mengalami stres dan tidak mampu mengatasinya akan mengalami kelelahan emosional, rasa frustasi, dan beresiko tinggi meninggalkan profesinya.

Lazarus (Taylor, 2006:115) menjelaskan proses terjadinya stres salah satunya akibat individu menilai sumberdaya yang dimilikinya tidak memadai dalam menghadapi stressor (penyebab stres). Ketika individu menghadapi situasi tertentu, ia akan masuk ke dalam level primary appraisal dan mempersepsi apakah situasi tersebut dianggap mengancam, netral, atau menyenangkan. Apabila persepsi individu melihat situasi tersebut sebagai ancaman, dalam proses selanjutnya yaitu secondary appraisal ia kemudian akan mengukur apakah memiliki sumber daya yang cukup untuk mengatasi situasi tersebut atau tidak. Reaksi stres kemudian muncul sebagai hasil proses secondary appraisal dimana individu merasa tidak memiliki sumber daya yang memadai untuk menghadapi situasi menekan tersebut. Perasaan tidak berdaya inilah yang kemudian oleh Langer (Germer, Siegel, dan Fulton, 2005:35) disebut sebagai kondisi mindlessness, yaitu saat di mana pikiran terperangkap dalam pola yang dangkal sehingga tidak mampu memahami konteks suatu peristiwa secara utuh dan hanya terfokus pada penilaian baik-buruk peristiwa tersebut. Kondisi mindlessness menyebabkan individu kehilangan kontrol terhadap dirinya sendiri karena tidak menyadari reaksireaksi fisik yang menjadi alarm penyesuaian diri. Menghadapi situasi semacam ini individu harus memiliki kemampuan untuk mengakses potensi internalnya dalam bentuk kesadaran utuh (full conciousness) yaitu ketrampilan mindfulness.

\section{Mindfulness sebagai Atribut Positif}

Mindfulness berakar dari filosofi Buddha dan merupakan bentuk ketrampilan yang dapat membantu individu agar memiliki kesadaran dan tidak bersikap reaktif akan apa yang terjadi saat ini, sebuah cara untuk memaknai peristiwa baik positif, negatif, maupun netral sehingga mampu mengatasi perasaan tertekan dan menimbulkan kesejahteraan diri (Germer, Siegel, dan Fulton, 2005:68). Kabat-Zinn (1990:98) mendefinisikan mindfulness sebagai kesadaran yang muncul akibat memberi perhatian terhadap sebuah pengalaman saat ini secara disengaja dan tanpa penilaian agar mampu merespon dengan penerimaan, dan bukannya bereaksi, terhadap pengalaman yang dialami seharihari.

Menurut definisi operasionalnya, mindfulness adalah kapasitas untuk: (a) observing: kemampuan observasi dan menyadari adanya pikiran, perasaan, persepsi, dan sensasi, (b) describing: mendeskripsikan dengan kata-kata, (c) acting with awareness: bertindak dengan penuh kesadaran, (d) nonreactivity: bersikap non-reaktif terhadap pengalaman pribadi, dan (e) nonjudge: bersikap tanpa penilaian terhadap pengalaman pribadi (Roeser et al, 2012:54).

Pada kenyataannya, kita sebagai manusia hanya memberi sedikit perhatian pada pengalaman yang sedang kita alami; sementara kesadaran akan pikiran dan perasaan justru teralihkan pada pengalaman eksternal lain, interaksi dengan orang lain, pemikiran akan masa 
lalu, ataupun ketakutan pada masa depan. Sebagian waktu kita berjalan dalam mode autopilot, dimana kita terperangkap dalam pengalaman dan bereaksi secara otomatis, terutama ketika kita berada dalam situasi penuh tekanan.. Kondisi mindlessness semacam ini menyebabkan individu kehilangan kontrol terhadap dirinya sendiri karena tidak menyadari reaksireaksi fisik yang menjadi alarm penyesuaian diri. Pada titik inilah kemudian seringkali individu mempersepsi dirinya sedang berada dalam kondisi stress akibat ketidakmampuannya merespon situasi dengan cara yang tepat.

Profesi guru dalam pendidikan usia dini merupakan peran yang sangat menantang. Guru PAUD dituntut terlibat secara fisik dengan kegiatan peserta didik sehingga membutuhkan kesiapan fisik yang matang. Sangat jarang dalam praktik mengajarnya guru PAUD memiliki kesempatan untuk duduk dan beristirahat karena kondisi kelas cenderng terus bergerak dinamis. Selain itu guru PAUD juga dituntut sehat secara mental dan emosional karena secara simultan harus terus menjaga kewaspadaan serta mencari cara baru dalam proses pembelajaran siswa.

Kebutuhan guru akan kesiapan fisik, mental, dan emosional baik untuk mewujudkan pembelajaran yang efektif maupun sebagai sumberdaya dalam mengatasi stres menunjukkan bahwa guru memerlukan ketrampilan mindfulness sebagai atribut positif yang dapat digunakan dalam keseharian.

Melalui mindfulness, guru dapat mengatasi stress yang mungkin dialami ketika berhadapan dengan anak didik, orangtua, meupun rekan kerja dengan lebih responsif. Kabat-Zinn (2003:150) menyebutkan kesadaran yang muncul pada kondisi mindful akan membantu seseorang melihat situasi yang menekan secara lebih jelas, sehingga muncul sudut pandang baru dalam melihat permasalahan maupun alternatif pemecahannya Kondisi mindful akan memberikan kesadaran pada individu bahwa ia memiliki kontrol terhadap pilihan-pilihannya sehingga mendorong munculnya sikap responsif, bukannya reaktif terhadap situasi di sekitarnya.

\section{Intervensi Berbasis Mindfulness}

Saat ini terdapat beberapa intervensi berbasis mindfulness yang dianggap memiliki dukungan empirik terbaik, dan dua diantaranya adalah Mindfulness Based Stres Reduction (MBSR) dan Mindfulness Based Cognitive Therapy (MBCT).

Mindfulness Based Stres Reduction (MBSR) merupakan salah satu jenis terapi berbasis mindfulness yang fokus melatih kesadaran melalui teknik meditasi. Dengan berlatih mengobservasi sensasi tubuh (body scan meditation), individu dapat mencapai kondisi mindful dalam kehidupan sehari-harinya, termasuk ketika melakukan aktivitas rutin seperti berjalan, makan, berdiri, dll (Germer, Siegel, dan Fulton, 2005:65). MBSR bertujuan mengubah hubungan individu dengan situasi dan pikiran yang penuh stres. Hal ini dicapai dengan cara menurunkan reaksi emosional dan meningkatkan penilaian kognitif secara positif. Mindful Motherhood merupakan salah satu terapi mindfulness yang dikembangkan dari MBSR dan telah terbukti mampu mengatasi stres, depresi, dan kecemasan pada subjek ibu hamil.

Mindfulness-Based

Therapy (MBCT) adalah intervensi berbasis mindfulness yang mengintegrasikan aspek Cognitive Behavioral Therapy (CBT) ke dalam format MBSR dalam sesi yang berdurasi lebih singkat. Awalnya intervensi ini digunakan terhadap pasien yang mengalami depresi berat yang kronis. Intervensi ini menambahkan elemen tradisional seperti psikoedukasi dan latihan untuk membedakan pikiran dan fakta. Namun MBCT lebih fokus untuk mengajak pasien menggunakan pendekatan decentered terhadap pengalaman internal daripada mengajarkan klien untuk merubah pikiran (Crane, 2009:87). 
Intervensi berbasis mindfulness pada studi ini selanjutnya akan disebut dengan Pelatihan "Smiling Mind" (SM) yang dikembangkan berdasar konsep Mindfulness Based Stres Reduction dan Mindfulness Based Cognitive Therapy. Pelatihan SM bertujuan untuk meningkatkan keterampilan mindfulness sebagai salah satu strategi koping terhadap stres sehingga peningkatan pada variabel ini dapat diasosiasikan dengan penurunan tingkat stres guru PAUD. Fokus pelatihan SM adalah kemampuan individu untuk menyadari segala reaksi fisik dan psikologis yang dialami dari waktu ke waktu. Diharapkan hasil penelitian ini selanjutnya dapat menjadi alternatif intervensi bagi peningkatan kesejahteraan psikologis guru .

Berdasarkan definisi dan bukti efektivitas mindfulness dari sejumlah penelitian sebelumnya, maka peneliti membangun asumsi dasar bahwa mindfulness sebagai konstruk psikologis memiliki pengaruh terhadap stress kerja pada guru PAUD.

\section{METODE}

\section{Jenis Penelitian}

Penelitian ini merupakan penelitian eksperimen. Metode kuasi eksperimen dilakukan untuk menguji pengaruh pelatihan berbasis mindfulness yang selanjutnya disebut pelatihan 'Smiling Mind' (SM) terhadap penurunan stres pada profesi guru PAUD. Desain kuasi eksperimen yang digunakan dalam penelitian ini adalah one group pretestpostest design yang mengukur tingkat stres guru PAUD sebelum dan sesudah dilaksanakannya intervensi.

\section{Subjek Penelitian}

Protokol pelatihan berbasis mindfulness umumnya dilakukan dalam kelompok kecil berjumlah maksimal 10 orang karena pelatihan ini membutuhkan intensitas yang padat. Selanjutnya partisipan yang terlibat dalam penelitian ini adalah 5 orang dengan kriteria sebagai berikut:
1. Berstatus sebagai guru PAUD

2. Berusia 20-35 tahun

3. Telah memiliki pengalaman mengajar minimal 1 tahun

3. Tingkat pendidikan minimal SLTA atau sederajat

4. Berdomisili di Yogyakarta

5. Tidak memiliki riwayat gangguan psikologis yang berhubungan dengan stres atau gangguan psikologis berat lainnya.

Populasi yang dijaring berdasarkan kriteria tersebut berasal dari 3 cabang TK Khalifah Yogyakarta. Partisipan kemudian dipilih dengan metode purposive sampling. Peneliti meminta rekomendasi kepada kepala sekolah untuk menunjuk guru yang sekiranya sesuai untuk mengikuti pelatihan Smiling Mind. Setelah itu peneliti memberikan penjelasan kepada para guru untuk selanjutnya guru yang berminat dapat mendaftarkan diri. Hal ini penting dilakukan agar partisipan dapat mengikuti proses pelatihan sesuai keinginannya sendiri. Adapun kelima partisipan tersebut adalah:

Tabel 1. Deskripsi subjek penelitian

\begin{tabular}{ccccc}
$\begin{array}{c}\text { N } \\
\text { o }\end{array}$ & Nama & Usia & $\begin{array}{c}\text { Pendidikan } \\
\text { Terakhir }\end{array}$ & $\begin{array}{c}\text { Lama } \\
\text { Mengajar }\end{array}$ \\
\hline 1 & BL & 26 th & SMK & 2 th \\
\hline 2 & IC & 24 th & SMA & 2 th \\
\hline 3 & ID & 29 th & SMA & 5 th \\
\hline 4 & PP & 28 th & D2 & 3,5 th \\
\hline 5 & YN & 35 th & SMA & 9 th
\end{tabular}

\section{Instrumen Penelitian}

Alat pengumpulan data yang digunakan dalam penelitian ini adalah :

Kuesioner Stres Guru, merupakan skala stres kerja yang disusun sendiri oleh peneliti. Skala ini disusun berdasarkan teori Taylor (2006:101) dan disesuaikan dengan hasil asesmen lapangan dimana stres dapat tampak melalui aspek fisik, emosi, kognitif, dan perilaku. Kuesioner ini terdiri atas 34 aitem pernyatan dan memiliki koefisien reliabilitas sebesar 0.909 


\section{Rancangan Perlakuan}

Perlakuan dalam penelitian ini adalah intervensi dengan bentuk pelatihan berbasis mindfulness yang selanjutnya akan disebut dengan 'Smiling Mind' (SM). Pelatihan ini bertujuan memunculkan kesadaran yang timbul akibat memberi perhatian terhadap sebuah pengalaman saat ini secara disengaja dan tanpa penilaian agar mampu merespon dengan penerimaan, dan bukannya bereaksi, terhadap pengalaman yang dialami seharihari (Kabat-Zinn, 2003:154) dengan cara fokus pada peningkatan kemampuan mengobservasi atau mengamati perubahan kondisi psikologis (Brown dan Ryan, 2003:840).

Terdapat 5 komponen mindfulness yang akan menjadi sasaran ketercapaian , yaitu: (a) observing: kemampuan observasi dan menyadari adanya pikiran, perasaan, persepsi, dan sensasi, (b) describing: mendeskripsikan dengan katakata, (c) acting with awareness: bertindak dengan penuh kesadaran, (d) nonreactivity: bersikap non-reaktif terhadap pengalaman pribadi, dan (e) nonjudge: bersikap tanpa penilaian terhadap pengalaman pribadi. Kelima komponen mindfulness tersebut akan dilatihkan kepada subjek penelitian melalui psikoedukasi dan praktik mindful formal serta informal.

Pelatihan ini merupakan program berkelompok yang terdiri dari 7 sesi dalam $3 \mathrm{x}$ pertemuan, dengan durasi masing-masing pertemuan selama 150180 menit. Selama pelatihan, subjek diberikan jurnal harian untuk diisi baik selama pelatihan berlangsung maupun sebagai catatan hasil latihan di rumah. Jurnal harian ini sekaligus digunakan oleh peneliti sebagai alat untuk mencatat perubahan perilaku yang dialami subjek.

Materi pelatihan Smiling Mind adalah psikoedukasi tentang stres, mindfulness dan pikiran otomatis, serta latihan praktik mindfulness yang secara umum dibagi menjadi teknik mindful formal (mindful check in, mindful breathing, body scan, meditasi kecemasan dan stres, serta meditasi cinta dan kebaikan), dan mindful informal (mindful eating, mindful walking,). Berbagai macam teknik tersebut dilakukan selama proses pelatihan dan dilanjutkan secara mandiri di luar pelatihan.

\section{Teknik Analisis}

Analisis data kuantitatif untuk menguji hipotesis dilakukan melalui analisis skor yang diperoleh (gain score) dari kuesioner stres guru pada saat sebelum dan setelah pelatihan dengan menggunakan teknik non-parametrik Wilcoxon matched-pairs signed-ranks test. Teknik non-parametrik digunakan sebab data pada penelitian ini berasal dari jumlah sample kecil sehingga data tidak terdistribusi normal dan jenis data yang dihasilkan adalah data ordinal.

\section{HASIL DAN PEMBAHASAN}

Hasil analisis uji signifikansi menunjukkan pelatihan Smiling Mind (SM) mampu menurunkan tingkat stres kerja pada guru PAUD. Hasil pengukuran menunjukkan bahwa rata-rata skor sstres partisipan pada saat pretest adalah sebesar 78.60, dan skor rata-rata pada saat posttest sebesar 68.60, terdapat penurunan ratarata skor stres kerja sebesar 10.0 poin. Berdasarkan analisis kuantitatif partisipan mengalami penurunan skor distres yang signifikan pada saat posttest dibandingkan dengan saat pretest yang ditunjukkan oleh nilai $\mathrm{z}=-2,023$ dan $\mathrm{p}=0,043(\mathrm{p}<0,05)$. Deskripsi skor stres tiap partisipan yang diperoleh pada saat pengukuran pretest dan posttest disajikan lebih lanjut melalui histogram berikut ini:

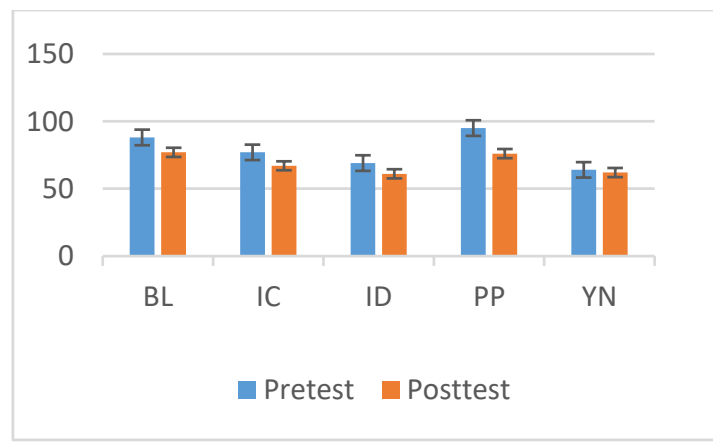

Gambar1. Pengukuran pretest-posttest 
Keberhasilan penelitian ini ditunjukkan oleh data yang dianalisis secara kuantitatif dan kualitatif. Seluruh partisipan mengaku mempraktikkan mindfulness dapat memberikan mereka pilihan baru tentang bagaimana berespon secara aktif terhadap stresor, alih-alih bereaksi secara otomatis seperti sebelumnya. Pelatihan SM memberikan kesempatan pada partisipan untuk mampu mengeksplorasi sumber daya internal yang sebelumnya belum disadari keberadaannya menjadi lebih optimal.

Partisipan PP dan BL yang menunjukkan keaktifan dalam berlatih mindfulness menyatakan, kesadaran akan respon diri baik fisik maupun proses mental membantu mereka menyadari bahwa mereka memiliki pilihan untuk merespon suatu peristiwa serta untuk melihat stresor melalui sudut pandang baru. Hal ini menunjukkan bahwa pada proses secondary appraisal partisipan mampu mengakses sumber daya internal sebagai bentuk manajemen stres. KabatZinn (1990:34) menyebutkan saat kondisi mindful tercapai, perhatian tidak akan terfokus pada masa lalu ataupun masa depan, dan individu tidak akan memberikan penilaian atau menolak apa yang sedang terjadi saat ini. Kesadaran yang muncul akan membantu individu melihat situasi ini secara lebih jelas, sehingga muncul sudut pandang baru dalam melihat permasalahan maupun alternatif pemecahannya.

Paradigma stres kehidupan memiliki tiga domain konseptual yang saling berkaitan, yaitu: (1) sumber stres, (2) moderator stres (sumber daya sosial dan koping), dan (3) akibat /efek stres. Sumber daya koping berfungsi untuk: (1) mengubah makna dari suatu peristiwa sehingga stres akan berkurang, (2) memodifikasi atau menghapuskan kondisi-kondisi yang mengarah pada permasalahan, atau (3) mengatur level respon emosional terhadap stresor (Flook et al, 2013:87). Dalam hal ini, ketrampilan mindfulness yang didapat partisipan melalui pelatihan Smiling Mind merupakan sumber daya koping baru yang dapat mereka gunakan untuk mengubah makna dari suatu peristiwa (stressful event) dan mengatur level emosional sehingga dampaknya dapat berkurang secara alami. Sumber daya koping yang baik tersebut pada akhirnya akan mampu memoderasi dan membantu individu mengurangi dampak buruk stres.

Data kualitatif yang didapat menunjukkan telah adanya upaya dari partisipan untuk menerapkan mindfulness di lingkungan sekolah. BL, IC, dan ID adalah partisipan yang tergolong aktif mempraktikkan latihan mindfulness informal dimana jenis latihan ini membutuhkan individu melakukan kontak yang lebih nyata dengan lingkungan. Sebagai partisipan dengan pengalaman mengajar yang belum terlalu banyak, BL dan IC sebelumnya kerap merasa kewalahan ketika menghadapi berbagai problem di kelas terutama pada anak-anak yang membutuhkan pengkondisian khusus. Praktik mindfulness di ruangruang kelas diakui $\mathrm{BL}$ dan IC memberi mereka ruang untuk 'bernapas', sehingga alih-alih terseret pada harapan-harapan mereka sendiri, saat ini mereka lebih mampu melihat situasi sulit tersebut sebagai tantangan yang harus diterima dengan penuh kasih sayang.

Hasil analisis menunjukkan ada beberapa faktor yang mempengaruhi keberhasilan partisipan mempraktikkan mindfulness yang selanjutnya berkorelasi terhadap penurunan stres. Partisipan yang mempraktikkan minimal dua teknik mindfulness yang diajarkan dalam kehidupan sehari-hari menunjukkan penurunan stres yang lebih konsisten. Brown \& Ryan (2003:88) menyebutkan keberhasilan penggunaan teknik mindfulness dipengaruhi oleh keaktifan partisipan untuk berlatih dan mengulang apa yang telah dipelajari selama pelatihan dalam kehidupan sehari-hari. Selain itu diperlukan pula karakteristik keterbukaan pada pengalaman, motivasi, dan sikap 'menjadi' alih-alih sekedar 'melakukan' (Kabat-Zinn, 1990:95). Pada level kognitif 
diperlukan partisipan yang setidaknya memiliki level pendidikan yang sama, agar muatan materi dan penggunaan bahasa dapat digunakan secara merata untuk semua partisipan

Hasil pengukuran pada setiap aspek stres menunjukkan penurunan paling signifikan terdapat pada domain fisik. Hal ini nampak dari pengukuran posttest dimana rerata stres aspek fisik mengalami penurunan terbesar dibandingkan rerata aspek lainnya, dilanjutkan dengan aspek emosi, perilaku, dan yang terakhir aspek kognitif. Penjelasan lebih lanjut mengenai deskripsi penurunan stres per-aspek dapat dilihat pada tabel berikut:

Tabel 2. Statistik Deskriptif Per-Aspek Variabel Stres

\begin{tabular}{lcc}
\hline Variabel & $\begin{array}{c}\mathrm{M} \\
\text { pretest }\end{array}$ & $\begin{array}{c}\mathrm{M} \\
\text { Posttest }\end{array}$ \\
\hline Stres & 78,60 & 68,60 \\
\hline Aspek fisik & 21,20 & 18,20 \\
\hline Aspek emosi & 19,60 & 16,80 \\
\hline $\begin{array}{l}\text { Aspek } \\
\text { kognitif }\end{array}$ & 21,00 & 19,20 \\
\hline $\begin{array}{l}\text { Aspek } \\
\text { perilaku }\end{array}$ & 16,80 & 14,40
\end{tabular}

Perubahan pada aspek-aspek stres ini erat kaitannya dengan konsep mindbody connection pada praktik mindfulness. Dengan mindfulness, partisipan belajar mengendalikan isi pikir dan emosinya sehingga pada akhirnya mampu berefek positif pada fungsi-fungsi tubuhnya (Crane, 2009:245). Ketika pikiran dalam kondisi mindlessness, individu dapat kehilangan kontrol akan dirinya sehingga tidak mampu merespon kebutuhan dirinya, Sebaliknya ketika dalam kondisi mindful, arus pikir yang jernih mampu membantu individu melihat kondisi diri dan memutuskan respon apa yang sesuai bagi kondisi tersebut (Duncan, Coatsworth dan Greenberg, 2009:255). Dalam latihan dasar meditasi mindfulness, fokus pada aliran oksigen yang masuk membantu individu "hadir" secara pikiran pada saat itu sekaligus menyadari bagaimana tubuh merespon aliran oksigen tersebut. Proses kesadaran ini kemudian secara otomatis dapat mereduksi tekanan stres yang mungkin sebelumnya belum mereka sadari.

Sebelum mengikuti pelatihan SM ini seluruh peserta mengaku belum pernah mempraktikkan jenis meditasi apapun, sehingga salah satu efek utama praktik mindfulness yang dirasakan peserta adalah pada sensasi fisik ketika mereka secara sadar menaruh perhatian pada kondisi tubuh. Hal ini nampak pada saat teknik body scan dilatihkan, beberapa peserta merasakan adanya keluhan fisik yang sebelumnya tidak mereka sadari seperti pundak terasa kaku, pelipis berdenyut, lengan terasa berat atau sulit digerakkan, hingga kram di bagian perut bawah. Sensasi mengenali tubuh dengan lebih seksama inilah yang menyebabkan peserta lebih mudah mengasosiasikan mindfulness dengan kesadaran fisik dibanding ketiga aspek lainnya.

Keterbatasan penelitian ini ada pada alat ukur yang hanya menggunakan satu instrumen yaitu Kuesioner Stres Guru yang disusun berdasar 4 domain stres yaitu fisik, kognitif, afektif, dan perilaku. Penggunaan alat ukur ini dilatarbelakangi kesulitan peneliti menemukan alat ukur yang aitem-aitemnya mampu mengukar stres guru PAUD di Indonesia yang memiliki sumber stres lebih spesifik dibanding stres kerja pada umumnya. Penggunaan instrumen tersebut memang menunjukkan adanya penurunan pada tingkat stres guru sebelum dan sesudah intervensi, akan tetapi belum dapat untuk mengungkap stres guru dalam konteks hubungan dengan anak didik, rekan seprofesi, orangtua murid, maupun lingkungan sekitar. Selain itu intervensi dengan model small gorup, membutuhkan penggalian data secara lebih komprehensif sehingga dapat dibandingkan antara capaian satu alat ukur dengan alat ukur lainnya.

Keterbatasan lain ada pada durasi dan materi pelatihan yang cukup padat. Pelatihan MBSR (Mindfulness Based Stress Reduction) dan MBCT 
(Mindfulness Based Cognitive Therapy) yang dijadikan dasar dalam menyusun modul pelatihan Smiling Mind dalam penelitian ini dilakukan dalam kurun waktu 8-10 minggu, meliputi satu pertemuan setiap minggunya dengan durasi 150-180 menit per pertemuan (Crane, 2009; Kabatt-Zin, 2003). Beberapa contoh implementasi MBSR bahkan menyertakan satu kali pertemuan dengan durasi 12 jam dalam rangkaian pelatihan agar mampu memfasilitasi peserta untuk berlatih teknik mindfulness secara terus menerus. Hal ini berguna untuk memastikan agar peserta pelatihan mampu mempertahankan kebiasaan mempraktikkan seluruh teknik mindfulness yang diajarkan walaupun pelatihan telah berakhir.

Penyusunan sesi pelatihan sebanyak tiga kali pada pelatihan SM ini karena memperhitungkan kondisi partisipan yang juga memiliki tugas-tugas cukup berat sebagai guru. Faktor ini menyebabkan ada banyak kemungkinan mortalitas pada partisipan sehingga dibutuhkan sesi pelatihan yang tidak terlalu lama. Akan tetapi hal ini pada akhirnya memberi dampak konsekuensi lain yaitu muatan materi pelatihan yang dirasa terlalu berat, apalagi terdapat partisipan dengan kemampuan kognitif yang tidak setara. Dari 6 teknik mindfulness yang diajarkan, setiap partisipan rata-rata hanya mampu mempraktikkan 1-2 teknik secara mandiri di rumah. Konsekuensi lain dari dipadatkannya materi pelatihan berbasis mindfulness ini juga tampak pada perubahan rerata stres yang didominasi pada penurunan aspek fisik. Hal ini dimungkinkan akibat singkatnya masa latihan sehingga efek yang ditibulkan baru sebatas kesadaran fisik.

\section{PENUTUP \\ Simpulan}

Teknik meditasi berbasis mindfulness terbukti dapat diterapkan untuk mengatasi stres guru PAUD. Kondisi pekerjaan yang serba aktif dan dinamis dapat membuat guru merasa kehilangan kontrol akan diri dan lingkungannya. Terapi berbasis mindfulness membantu partisipan mengembalikan kontrol ini kepada dirinya, sehingga guru dapat berperan aktif memutuskan apa yang harus dilakukan tanpa harus menunggu bantuan/ sumberdaya eksternal.

Praktik mindfulness dapat digunakan guru baik ketika sedang menjalankan profesinya maupun dalam kondisi keseharian. Hasil terbaik akan diperoleh melalui latihan rutin mindful formal seperti teknik body scan, mindul check in, mindful breathing, serta mindful informal seperti teknik mindful walking dan mindful eating.

Mindfulness terbukti dapat diajarkan pada subjek guru yang sebelumnya belum pernah mempraktikkan meditasi, akan tetapi perlu diperhatikan susunan pelatihan agar kesadaran akan kondisi tubuh tidak hanya terbatas pada fisik saja namun juga pada aspek emosi, kognitif, dan perilaku.

Hasil ini menunjukkan protokol pelatihan berbasis mindfulness dapat dikembangkan sebagai intervensi peningkatan kesejahteraan psikologis guru.

\section{Saran}

Teknik mindfulness yang diberikan pada partisipan sebaiknya selalu dikaitkan dengan keempat aspek stres. Hal ini perlu dilakukan sehingga meskipun sensasi fisik adalah aspek yang paling mendapat efek langsung, namun peserta dapat juga memiliki kesadaran mendalam akan emosi, pikiran, dan perilakunya. Fasilitator perlu berperan lebih dalam untuk membantu peserta memahami ketiga aspek lainnya.

Apabila akan dilakukan penelitian serupa selanjutnya sebaiknya menggunakan lebih dari satu instrumen sebagai alat ukur stres. Kondisi stres yang dirasakan guru di tempat kerja umumnya berhubungan dengan stres di lingkungan lainnya sehingga diperlukan alat ukur 
pembanding agar didapat data yang lebih komprehensif.

Terakhir, Pada penelitian selanjutnya agar menggunakan desain yang memungkinkan adanya generalisasi pada populasi lebih luas, misalkan menggunakan kelompok kontrol atau memperbesar jumlah partisipan pelatihan. Pengukuran follow-up juga diperlukan untuk mengetahui kebermanfaatan praktik mindfulness pada partisipan.

\section{DAFTAR PUSTAKA}

Bauer, J., Stamm, A., Virnich, K., Wissing, K., Muller, U., Wirsching, M., (2006). Correlation Between Burnout Syndrome and Psychologycal and Psychosomatic Symptomp Among Teachers. International Archives of Occupational and Environmental Health, 79, 199-204

Brown, K. W., \& Ryan, R. M., (2003). The Benefits of Being Present: Mindfulness and It's Role in Psychological Wellbeing. Journal of Personality and Social Psychology, $84,822-848$

Crane, R. (2009). Mindfulness Based Cognitive Therapy: Distinctive Features. New York: Routledge Publication

Duncan, L. G., Coatsworth, J. D., \& Greenberg, M. T. (2009). A Model of Mindful Parenting: Implications for Parent-Child Relationship and Prevention Research. Clinical Child Family Psychology Rev, 12:255270

Flook, L., Goldberg, S. B., Pinger, L., Bonus, K., \& Davidson, R., (2013). Mindfulness For Teachers: A Pilot Study To Assess Effects On Stress, Burnout, and Teaching Efficacy. Journal Compilation Of International Mind, Brain, and Education, 7:182-195

Germer, C. K., Siegel, R. D., \& Fulton, P. R. (2005). Mindfulness and
Psychotherapy. New York: The Guilford Press

Jennings, P. A., \& Greenberg, M. (2009). The Prosocial Classroom: Teacher Social and Emotional Competence in Relation to Child and Classroom Outcomes. Review of Educational Research, 79, 491-525

Kabat-Zinn, J. (1990). Full Catasthrope Living: Using the Wisdom of Your Body and Mind to Face Stress, Pain and Illness. New York: Bantam Dell.

Kabat-Zinn, J. (2003). Mindfulnes-based Interventions in Context: Past, Present, and Future. Clinical Psychology: Science and Practice, 10, 144-156

Khilmiyah, Akif. 2012. Stres Kerja Guru Perempuan di Kecamatan Kasihan Bantul Yogyakarta. Lentera pendidikan, Vol 15 (2), 135-143

McCallum, F., \& Price, D. (2010). Well Teachers, Well Student. Journal of Student Wellbeing, 4 (1), 19-34

McCormick, J. \& Barnett, K. (2011). Teacher's Attribution for Stress and Their Relationship with Burnout. International Journal of Educational Management, Vol 25 (3), 278-293

Roeser, R. W., Skinner, E., Beers, J., \& Patricia, A. J., (2012). Mindfulness Training and Teacher's Professional Development : An Emerging Area of Research and Practice. Child Development Perspectives, 6 (2), 167-173

Schoeberlein, Deborah. (2009). Mindful Teaching and Teaching Mindfulness. Somerville: Wisdom Publications

Snyder, C. R., \& Lopez, S. J. (2007). Positive Psychology: The Scientific and Practical Explorations of Human Strength. London: Sage Publications

Taylor, S, E. (2006). Health Psychology 6th Edition. Singapore: McGrawHill 